\title{
ALTERNATIF UJI BEBAN PADA STRUKTUR (STUDI KASUS : JEMBATAN BAJA)
}

\author{
Chairul Soleh $^{1}$, Josia Irwan Rastandi ${ }^{2}$ \\ ${ }^{1}$ Magister Teknik Sipil, Universitas Tarumanagara, Jakarta \\ Email: chairulshafa@gmail.com \\ ${ }^{2}$ Magister Teknik Sipil, Universitas Tarumanagara, Jakarta \\ ${ }^{2}$ Jurusan Teknik Sipil, Universitas Indonesia, Depok \\ Email:jrastandi@gmail.com
}

Masuk: 31-01-2020, revisi: 13-01-2021, diterima untuk diterbitkan: 27-02-2021

\begin{abstract}
ABSTRAK
Uji beban struktur yang umum dan sudah banyak dilakukan adalah uji beban statik. Alternatif lain dari uji beban adalah dengan melakukan pengujian vibrasi (dinamik) pada struktur. Pengujian vibrasi (dinamik) dilakukan untuk mengetahui tingkat kekakuan struktur atau elemen struktur berupa frekuensi alami, sedangkan uji beban statik dimaksudkan untuk mendapatkan respons hasil pembebanan statik dari struktur berupa lendutan. Pembahasan akan menekankan kepada korelasi antara uji beban statik dan uji beban vibrasi (dinamik). Untuk mengkorelasikan pengujian beban statik terhadap pengujian vibrasi (dinamik) diperlukan suatu acuan atau nilai yang berasal dari analisa pemodelan atau teoritis. Pemodelan struktur dilakukan untuk mendapatkan frekuensi alami secara teoritis dan lendutan teoritis yang kemudian akan dibandingkan dengan frekuensi alami hasil uji vibrasi (dinamik). Jika frekuensi hasil uji dan frekuensi teoritis dibandingkan terhadap lendutan teoritis maka akan didapatkan prediksi lendutan uji. Hasil korelasi antara prediksi lendutan uji terhadap lendutan uji beban statik cukup mendekati dengan perbedaan kurang dari $12 \%$. Dilihat dari korelasi diatas, maka untuk pemeriksaan berkala pada struktur yang telah diuji dapat dipertimbangkan untuk dilakukan pengujian vibrasi saja. Jenis struktur yang ditinjau adalah struktur jembatan baja simple span, simple span + link slab dan continuous span.
\end{abstract}

Kata kunci: frekuensi alami; pengujian dinamik; pengujian static; pemodelan

\begin{abstract}
The most common structural load test that has been widely used is the static load test. An alternative to the structural load test is dynamic load test. Dynamic testing is a test carried out to determine level of structural stiffness or structural elements stiffness in the form of natural frequencies, while the static load test is intended to obtain responses of static loading from the structure in the form of deflection. The discussion will emphasize the correlation between static load test and dynamic load test. To correlate the static load test with the vibration test, a reference or value that comes from modeling or theoretical analysis is needed. Structural modeling is carried out to obtain the theoretical natural frequency and the theoretical deflection which will then be compared with the natural frequency of the vibration test (dynamic). If the frequency of the test results and the theoretical frequency are compared to the theoretical deflection, the prediction of the test deflection will be obtained. The correlation between the predicted deflection of the test and deflection of the static load test is quite close with a difference of less than $12 \%$. Judging from the above correlation, periodic inspections of the tested structures can be considered for vibration testing only. The types of structures reviewed are simple span steel bridge structure, simple span + link slab steel bridge structure and continuous span steel bridge structure.
\end{abstract}

Keywords: modeling; natural frequencies; vibration testing; static load test 


\section{PENDAHULUAN}

\section{Latar Belakang}

Pembangunan baik struktur maupun infrastruktur dimaksudkan untuk menciptakan pertumbuhan perekonomian. Pembangunan yang merata disemua daerah dapat menumbuhkan pusat perekonomian baru secara merata dan menghilangkan kesenjangan ekonomi antar daerah. Oleh karena itu, maka Pemerintah dengan gencar melakukan berbagai macam pembangunan baik struktur maupun infrastruktur. Banyaknya pembangunan yang dilakukan haruslah sesuai dengan apa yang sudah direncanakan atau sesuai dengan desain dan perhitungan. Selain itu, proses pembangunan juga harus diperhatikan guna mencegah terjadinya kegagalan bangunan.

Kepastian mengenai struktur yang sudah dibangun sesuai dengan desain sangat diperlukan karena menyangkut kepentingan orang banyak. Untuk memastikan hal itu dan ditambah lagi apabila ada keraguan pada struktur tersebut dapat dilakukan pengujian struktur baik itu uji material maupun uji strukturnya.

Uji material adalah pengujian yang dilakukan untuk mendapatkan sifat, properti, mutu maupun kondisi dari bahan material yang diuji baik itu baja atau beton tergantung bahan material apa yang dipakai dalam struktur. Sedangkan uji struktur adalah pengujian yang dilakukan pada struktur baik sebagian (lokal) atau seluruhnya dan terdiri dari uji statik dan uji dinamik. Pengujian statik lebih banyak diketahui dan sering dilakukan pada struktur baik gedung ataupun jembatan, dan telah mempunyai pedoman pasti seperti yang tertuang dalam SNI 03:2847. Pengujian dinamik belum banyak diketahui namun dapat mengacu kepada peraturan yang ada yaitu peraturan dari Departemen Permukiman dan Prasarana Wilayah Pt T-05-2002-B mengenai penilaian dinamis struktur. Penilaian kondisi bangunan atas jembatan berdasarkan kriteria yang diturunkan dari hasil penelitian adalah seperti pada Tabel 1 berikut :

Tabel 1. Penilaian kondisi bangunan atas jembatan

\begin{tabular}{cccc}
\hline Nilai Kondisi & Jenis Kerusakan & $\begin{array}{c}\text { Nilai Kerusakan Relatif } \\
D_{r e l}\end{array}$ & $\begin{array}{c}\text { Nilai Penurunan Kapasitas } \\
D_{c a p}\end{array}$ \\
\hline Baik & Utuh & $0 \%-5 \%$ & $0 \%-10 \%$ \\
\hline Cukup & $\begin{array}{c}\text { Rusak Ringan } \\
\text { (Non Struktural) }\end{array}$ & $6 \%-10 \%$ & $11 \%-20 \%$ \\
\hline Sedang & $\begin{array}{c}\text { Rusak Ringan } \\
\text { (Struktural) }\end{array}$ & $11 \%-17 \%$ & $21 \%-34 \%$ \\
\hline Buruk & $\begin{array}{c}\text { Rusak Berat } \\
\text { (Struktural) }\end{array}$ & $18 \%-20 \%$ & $35 \%-40 \%$ \\
\hline
\end{tabular}

$D_{\text {rel }}=\left(f_{\text {teoritis }}-f_{\text {actual }}\right) / f_{\text {teoritis }}$

Dimana :

$D_{\text {rel }} \quad=$ nilai kerusakan struktur relatif

$f_{\text {teoritis }}=$ frekuensi alami teoritis

$f_{\text {actual }}=$ frekuensi alami aktual

Pengujian statik dilakukan dengan waktu yang cukup lama, banyak tenaga dan banyak biaya sedangkan pada pengujian vibrasi (dinamik) dilakukan dengan waktu yang cukup singkat dan lebih efisien dari segi tenaga dan biaya. 


\section{Tujuan Penelitian}

Tujuan dari penelitian ini adalah untuk mengetahui tingkat akurasi uji dinamik dibandingkan uji statik.

Adapun ruang lingkup dalam penelitian ini adalah seperti pada Gambar 1 dan 2 berikut :

- Jenis struktur yang ditinjau

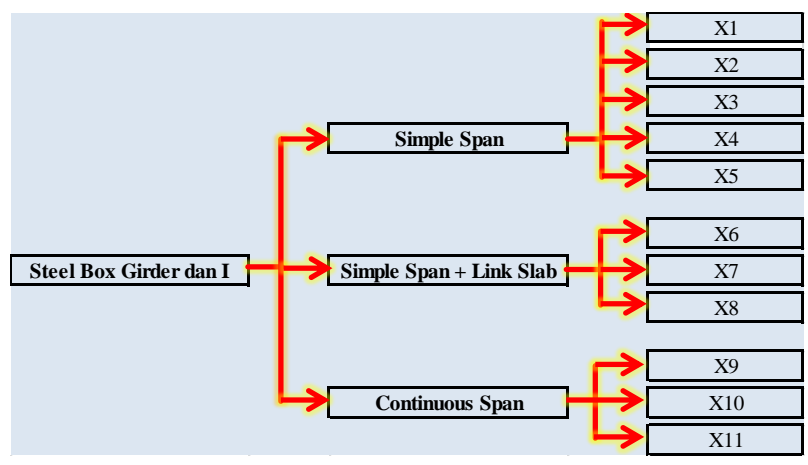

Gambar 1. Jenis struktur yang dilakukan uji beban
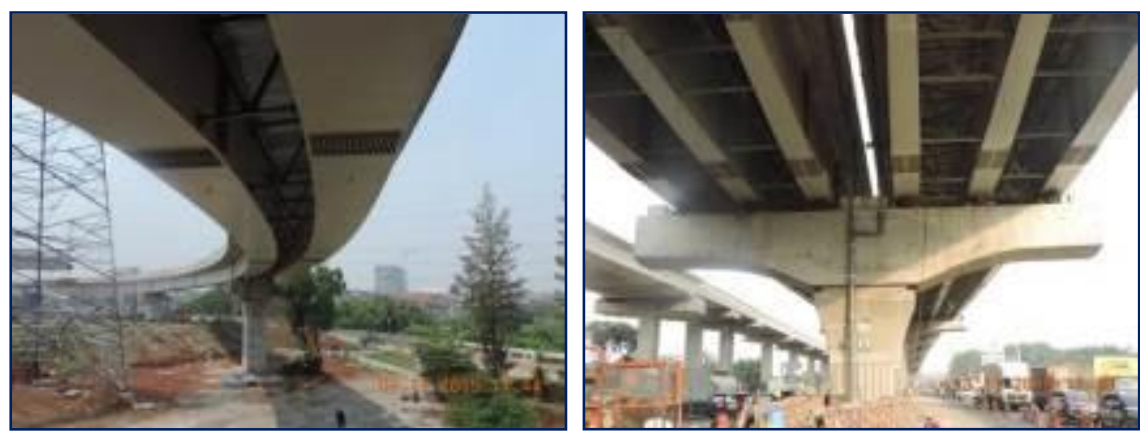

Gambar 2. Jenis struktur yang dilakukan pengujian (Box dan I) steel girder

Struktur yang diuji merupakan struktur girder baja komposit dengan pelat lantai beton. Girder baja yang digunakan yaitu steel box girder dan I-girder. Box girder digunakan untuk bentang sederhana dan bentang sederhana dengan link slab sedangkan I-girder digunakan untuk continuous span / bentang panjang.

- Beban uji statik menggunakan truk dengan total antara 70\% - 75\% beban hidup.

- Beban dinamik menggunakan beban kejut dari truk.

- Hasil uji yang akan dibandingkan adalah frekuensi alami dan lendutan vertikal.

\section{METODE PENELITIAN}

\section{Instrumen}

Metode penelitian adalah langkah yang dimiliki dan dilakukan dalam rangka untuk mengumpulkan informasi atau data serta melakukan investigasi pada data yang telah didapatkan tersebut. Metode yang digunakan dalam penelitian ini adalah berupa pengujian yang terbagi menjadi pengujian dinamik dan pengujian statik. Kemudian untuk pengambilan data dibutuhkan suatu instrumen pengukuran seperti Gambar 3 berikut : 


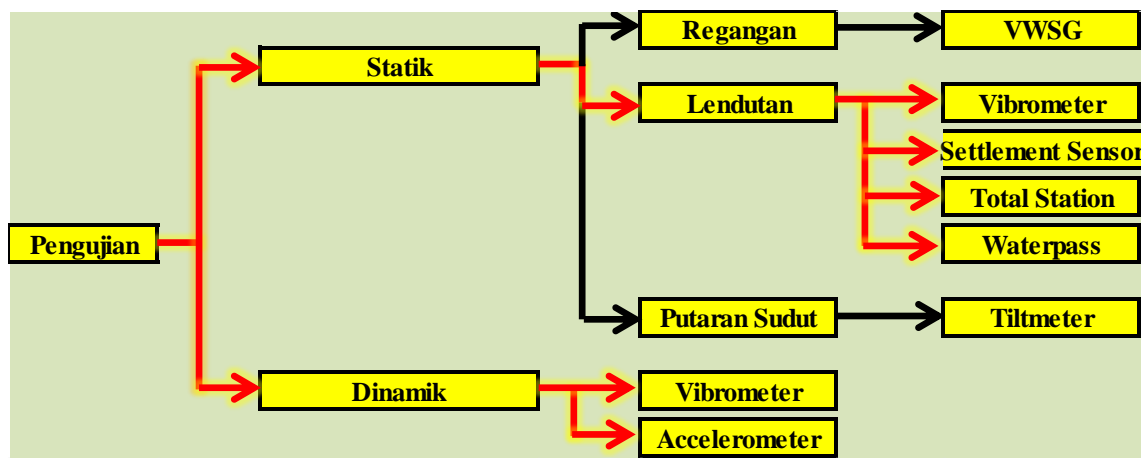

Gambar 3. Jenis Pengujian dan Instrumen yang digunakan

Skema yang digunakan dalam penelitian ini adalah mengikuti panah warna merah seperti terlihat pada Gambar diatas. Vibrometer digunakan karena mempunyai ketelitian yang lebih tinggi dibandingkan dengan waterpass atau total station, yaitu $35 \mu \mathrm{m}$. Vibrometer ini bersifat contactless sehingga pengukuran cukup menembakkan titik sasaran maksimum sejauh 500 meter. Sedangkan Settlement Sensor (SS) digunakan pada jembatan yang tidak bisa dipasang instrumen dibawah jembatan seperti jembatan yang melewati sungai ataupun ada jembatan lain dibawahnya. Pada Gambar 4 terlihat instrumen yang dipakai dalam pengujian ini.

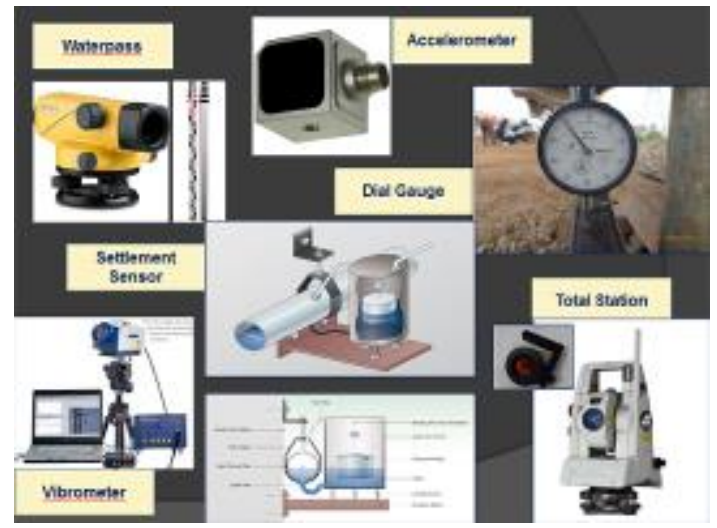

Gambar 4. Instrumen dalam pengujian

\section{Analisis}

Berdasarkan penemuan-penemuan dalam teori dan analisis struktur, kemudian dikembangkan oleh para ahli mengenai analisa dinamik struktur. Dalam mendesain sebuah struktur dapat dilihat perilaku struktur akibat beban yang bekerja. Beban yang diberikan pada struktur biasanya adalah beban statik, namun kenyataannya jarang sekali kita jumpai beban statik melainkan beban dinamik. Beban dinamik adalah suatu beban yang memiliki besaran, arah, atau titik aplikasi yang berhubungan dengan waktu. Beban dinamik yang bekerja pada struktur dapat dianalisa dan diketahui responnya, dimana respon dinamik yang dihasilkan adalah defleksi yang bervariasi terhadap waktu dan tegangan.

Mempelajari analisa dinamik dimulai dari struktur yang sederhana terlebih dahulu sehingga mudah dipahami. Struktur dikatakan sederhana karena diidealisasikan sebagai massa yang terkonsentrasi $(m)$ dengan disupport oleh suatu kekakuan $(k)$ dari elemen struktur. Dengan idealisasi tersebut dapat dibuat suatu model matematika yang dapat dipelajari. Perlu diketahui 
juga mengenai sistem degree of freedom dari suatu model yaitu banyaknya jumlah perpindahan yang harus dipertimbangkan untuk mewakili efek dari semua gaya inersia yang signifikan. Untuk memudahkan dalam mengetahui analisa dinamik, maka sistem degree of freedom yang perlu diketahui sebagai langkah awal adalah Sistem degree of freedom dengan derajat kebebasan satu atau single degree of freedom (SDOF). Kemudian dikembangkan lagi menjadi multi degree of freedom (MDOF). Menurut Roy. R. Craig. Jr, dalam mempelajari analisa dinamik SDOF dapat dimulai dari beberapa tahapan yaitu :

- Getaran bebas tanpa redaman pada sistem SDOF

- Respon sistem SDOF pada harmonic excitation

- Respon sistem SDOF pada periodic excitation : Analisa frekuensi domain, seperti Gambar 5 berikut.

- Respon sistem SDOF pada arbitrary excitation

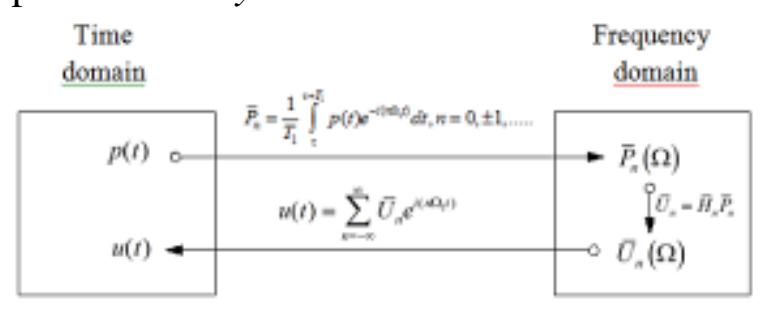

Gambar 5. Analisa frekuensi domain

Gabungan dari beberapa SDOF akan menjadi MDOF (Multi Degree Of Freedom) yang dapat dikembangkan dan menjadi dasar dari beberapa program analisis struktur. Teori dari analisa respon terhadap beberapa excitation juga dijadikan sebagai dasar penganalisaan hasil alat ukur getaran atau accelerometer. Pembahasan pada sistem tersebut akan dikenal mengenai deret fourier yang nantinya dipakai untuk merubah percepatan struktur menjadi frekuensi alami dengan metode Fast Fourier Transform. Pengujian dinamik yang menggunakan alat sensor accelerometer dapat mendeteksi getaran yang sangat sensitif dan mencatat respons percepatan dari struktur atau elemen struktur. Data respons percepatan yang didapatkan tersebut bisa ditransformasikan menjadi frekuensi alami dengan metode FFT (Fast Fourier Transform).

Hasil dari pengujian ini yang berupa frekuensi alami struktur dapat digunakan sebagai berikut :

a. Mengetahui tingkat ketidaknyamanan akibat getaran dalam bangunan.

Tingkat ketidaknyamanan akibat getaran yang terjadi dan dapat mempengaruhi aktivitas telah diteliti dan dipublikasikan dalam British Standard (BS 6841-1987) dan International Organization for Standardization (ISO 2631-1-1997).

b. Mengetahui perilaku struktur akibat beban getaran.

Getaran-getaran yang terjadi dapat berasal dari mesin, orang berjalan, laju kendaraan, dll. Akibat adanya getaran tersebut dapat dilakukan pengujian dinamik dengan uji vibrasi memakai alat accelerometer. Pengujian dinamik dapat dilakukan pada bangunan diantaranya jembatan, gedung, JPO, dermaga dll.

Struktur JPO yang diuji memiliki frekuensi yang berbeda-beda ketika manusia berjalan disepanjang struktur, frekuensi terbesar terjadi ketika beban dinamis manusia mencapai tengah bentang, namun perbandingan antara frekuensi akibat beban dinamis manusia dengan frekuensi alaminya kurang dari 0.5 sehingga struktur tidak terjadi resonansi (Wahyuni, 2012). 
Pengujian dinamik pada lantai bangunan dilakukan untuk melihat perilaku lantai terhadap getaran akibat pembebanan orang. Hasil yang didapatkan adalah berupa frekuensi yang akan dibandingkan dengan frekuensi alami dari pemodelan, jika frekuensinya lebih kecil dari yang disyaratkan maka pelat lantai tersebut harus diperkuat sehingga dapat mengurangi efek getaran dan frekuensinya menjadi lebih besar dari yang disyaratkan (Philipus, 2014).

c. Mengetahui tingkat penilaian dinamis struktur.

Penilaian dinamis struktur dapat dilakukan sesuai dengan peraturan yang ada yaitu peraturan dari Departemen Permukiman dan Prasarana Wilayah Pt T-05-2002-B. Peraturan penilaian dinamis ini lebih dikhususkan untuk struktur jembatan, peraturan ini membahas tentang penilaian kondisi jembatan untuk bangunan atas dengan cara uji getar. Untuk mengetahui tingkat penilaian dinamis struktur, maka dilakukan pengujian dinamik untuk mendapatkan frekuensi alami aktual struktur yang akan dibandingkan dengan frekuensi alami hasil pemodelan.

Selain pengujian dinamik pada penulisan ini juga nantinya akan dibahas mengenai pengujian statik. Pengujian ini dilakukan dengan memberikan beban kepada struktur baik itu struktur jembatan ataupun struktur gedung. Beban yang digunakan untuk struktur gedung dapat berupa beban air ataupun beban material yang disusun diatas pelat beton, sedangkan beban untuk struktur jembatan dapat menggunakan beban truk yang bermuatan. Pada penulisan ini lebih dititik beratkan pada pengujian untuk jembatan. Struktur jembatan yang diuji menggunakan peraturan SNI 1725-2016 untuk pembebanannya yaitu beban lajur " $D$ " terdiri dari beban terbagi merata (UDL) dan beban garis terpusat (KEL), seperti terlihat pada Gambar 6.

UDL mempunyai intensitas $\mathrm{q}(\mathrm{kPa})$ yang besarnya tergantung pada panjang total $\mathrm{L}$ yang dibebani dan dinyatakan dengan perhitungan sebagai berikut :

$\mathrm{q}=9.0 \mathrm{kPa}$ untuk $\mathrm{L} \leq 30 \mathrm{~m}$

$\mathrm{q}=9.0 *(0.5+15 / \mathrm{L}) \mathrm{kPa}$ untuk $\mathrm{L}>30 \mathrm{~m}$

KEL mempunyai intensitas, $\mathrm{p}=49.0 \mathrm{kN} / \mathrm{m}$

Faktor beban dinamis (Dinamic Load Allowance) untuk KEL diambil sebagai berikut :

DLA $=0.4$ untuk $\mathrm{L} \leq 50 \mathrm{~m}$

DLA $=0.4-0.0025 *(\mathrm{~L}-50)$ untuk $50<\mathrm{L}<90 \mathrm{~m}$

$\mathrm{DLA}=0.3$ untuk $\mathrm{L} \geq 90 \mathrm{~m}$

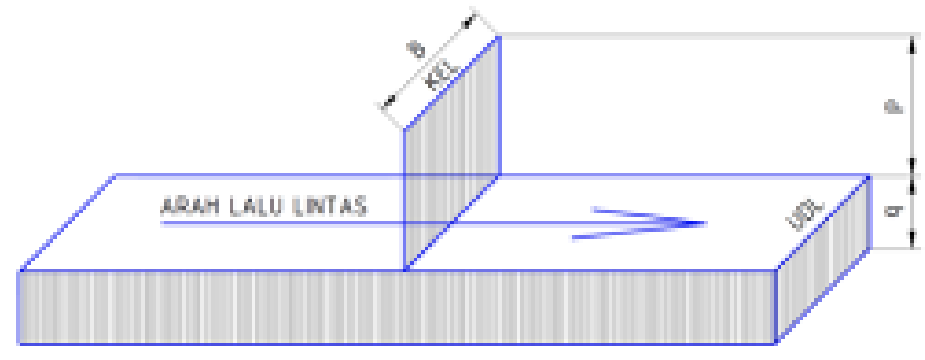

Gambar 6. Perhitungan beban sesuai SNI 1725-2016

\section{Modelisasi Struktur dan Pembebanan}

Berikut diberikan contoh modelisasi struktur untuk struktur X6 terlihat pada Gambar 7 berikut ini. 


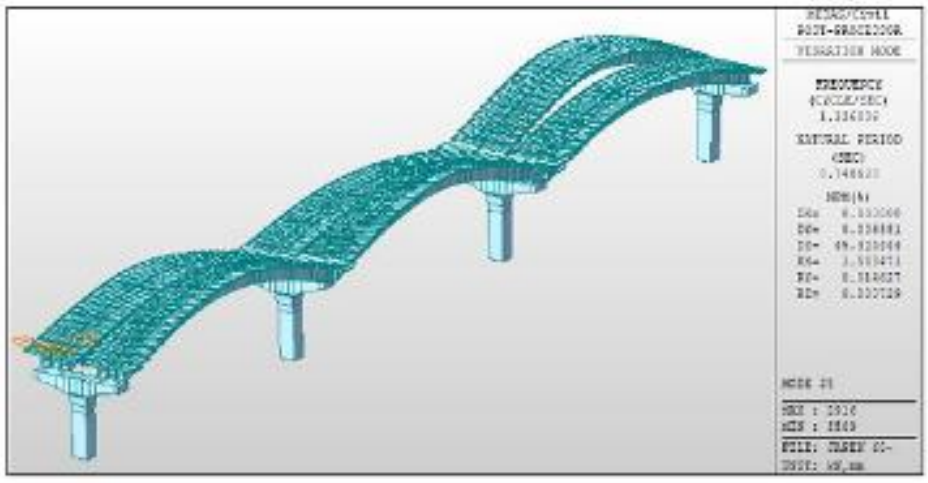

Gambar 7. Frekuensi vertikal alami untuk struktur X6

Pembebanan yang dilakukan untuk uji beban dinamik seperti terlihat pada Gambar 8 dilakukan dengan menggunakan roda depan truk bermuatan yang jatuh pada ketinggian $200 \mathrm{~mm}$, beban dari truk menjadi trigger bagi jembatan ke arah vertikal sehingga terjadi force vibration pada struktur. Uji beban statik yang terlihat pada Gambar 9 dimaksudkan untuk mendapatkan respons hasil pembebanan statik dari struktur jembatan berupa respons deformasi penurunan secara vertikal dari struktur.

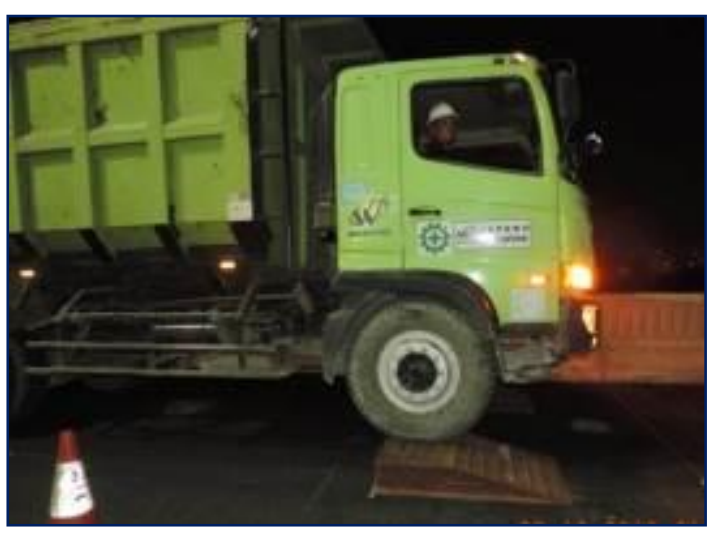

Gambar 8. Uji beban vibrasi (dinamik)

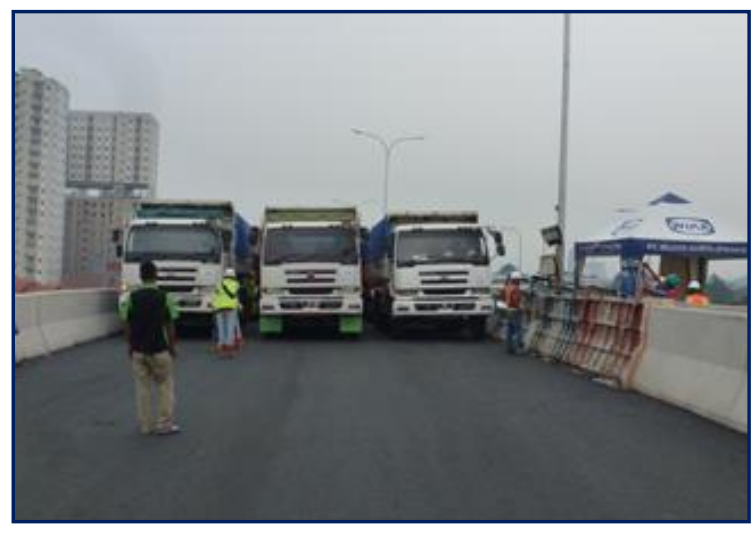

Gambar 9. Uji beban statik

\section{HASIL DAN PEMBAHASAN}

\section{Lendutan dan Frekuensi alami}

Pada Tabel 2 disajikan seluruh hasil pengujian yang telah dilakukan berupa lendutan dan frekuensi vertikal alami yang dibandingkan dengan lendutan dan frekuensi vertikal alami hasil pemodelan. Lendutan yang diambil adalah lendutan tengah bentang. 
Tabel 2. Perbandingan pengujian vibrasi (dinamik) dan statik terhadap analisa pemodelan

\begin{tabular}{|c|c|c|c|c|c|c|c|c|}
\hline \multirow{2}{*}{ Tipe Struktur } & \multirow{2}{*}{ Lokasi \& Jenis Struktur } & \multirow{2}{*}{ Beban Uji } & \multirow{2}{*}{ Total Beban Uji } & \multicolumn{2}{|c|}{ Lendutan Max (mm) } & \multicolumn{2}{|c|}{ Frekuensi (Hz) } & \multirow{2}{*}{ Drel } \\
\hline & & & & Teoritis & Hasil Uji & Teoritis & Hasil Uji & \\
\hline Simple Span & $\mathrm{X} 1$ & $73 \%$ & 300 Ton & 143.9 & 117.1 & 1.076 & 1.215 & $-12.9 \%$ \\
\hline \multicolumn{9}{|c|}{ Steel box girder $61.9 \mathrm{~m}$} \\
\hline & $\mathrm{X} 2$ & $71 \%$ & 384 Ton & 19.12 & 20.47 & 2.900 & 2.800 & $3.4 \%$ \\
\hline \multicolumn{9}{|c|}{ Steel box girder $35 \mathrm{~m}$} \\
\hline & $\mathrm{X} 3$ & $73 \%$ & 360 Ton & 68.45 & 62.84 & 1.346 & 1.330 & $1.2 \%$ \\
\hline \multicolumn{9}{|c|}{ Steel box girder $60 \mathrm{~m}$} \\
\hline & $\mathrm{X} 4$ & $73 \%$ & 360 Ton & 67.82 & 68.68 & 1.360 & 1.420 & $-4.4 \%$ \\
\hline \multicolumn{9}{|c|}{ Steel box girder $60 \mathrm{~m}$} \\
\hline & $\mathrm{X} 5$ & $73 \%$ & 360 Ton & 71.11 & 69.22 & 1.360 & 1.4 & $-2.9 \%$ \\
\hline \multicolumn{9}{|c|}{ Steel box girder $60 \mathrm{~m}$} \\
\hline Simple Span & $\mathrm{X} 6$ & $73 \%$ & 360 Ton & 79.66 & 64.03 & 1.340 & 1.44 & $-7.5 \%$ \\
\hline \multicolumn{9}{|c|}{ Steel box girder $60 \mathrm{~m}$} \\
\hline & $\mathrm{X} 7$ & $73 \%$ & 240 Ton & 55.87 & 67.8 & 1.430 & 1.34 & $6.3 \%$ \\
\hline \multicolumn{9}{|c|}{ Steel box girder $60 \mathrm{~m}$} \\
\hline & X7 Uji Ulang Setelah Diperkuat & $73 \%$ & 360 Ton & 63.99 & 60.2 & 1.375 & 1.481 & $-7.7 \%$ \\
\hline \multicolumn{9}{|c|}{ Steel box girder $60 \mathrm{~m}$} \\
\hline & $\mathrm{X} 8$ & $71 \%$ & 400 Ton & 75.77 & 69.11 & 1.15 & 1.22 & $-6.1 \%$ \\
\hline \multicolumn{9}{|c|}{ Steel box girder $75 \mathrm{~m}$} \\
\hline Continuоus & $\mathrm{X} 9$ & $73 \%$ & 276 Ton & 43.38 & 31.26 & 1.385 & 1.6 & $-15.5 \%$ \\
\hline \multirow[t]{4}{*}{ Span } & Steel box girder $60 \mathrm{~m}$ & & & & & & & \\
\hline & $\mathrm{X} 10$ & $71 \%$ & 552 Ton & 81.49 & 83.24 & 0.900 & 0.91 & $-1.1 \%$ \\
\hline & \multicolumn{8}{|l|}{ Steel I girder $120 \mathrm{~m}$} \\
\hline & $\mathrm{X} 11$ & $71 \%$ & 385 Ton & 22.00 & 27.18 & 0.950 & 0.9 & $5.3 \%$ \\
\hline & Steel I girder $70 \mathrm{~m}$ & & & & & & & \\
\hline
\end{tabular}

Dilihat dari Tabel diatas dapat diketahui simpangan yang terjadi pada pengujian dinamik dan statik terhadap analisa pemodelan. Pada Tabel 3 diberikan hasil simpangan tersebut.

Tabel 3. Simpangan hasil pengujian vibrasi (dinamik) dan statik terhadap analisa pemodelan

\begin{tabular}{c|cc}
\hline \multirow{2}{*}{ Lokasi Uji } & \multicolumn{2}{c}{ Simpangan (\%) } \\
\cline { 2 - 3 } & Frekuensi & Lendutan \\
\hline X1 & 12.92 & -18.62 \\
\hline X2 & -3.45 & 7.06 \\
\hline X3 & -1.19 & -8.20 \\
\hline X4 & 4.41 & 1.27 \\
\hline X5 & 2.94 & -2.66 \\
\hline X6 & 7.46 & -19.62 \\
\hline X7 & -6.29 & 21.35 \\
\hline X7 Setelah Diperkuat & 7.71 & -5.92 \\
\hline X8 & 6.09 & -8.79 \\
\hline X9 & 15.52 & -27.94 \\
\hline X10 & 1.11 & 2.34 \\
\hline X11 & -5.26 & 23.55 \\
\hline & &
\end{tabular}

Secara garis besar dapat kita lihat bahwa simpangan frekuensi bernilai positif artinya hasil pengukuran lebih besar dari teoritis dan simpangan lendutan bernilai negatif artinya hasil uji statik lebih kecil dari teoritis maka dapat dikatakan bahwa baik uji dinamik maupun uji statik memberikan kecenderungan yang sama yaitu struktur lebih kaku daripada hasil perhitungan secara teoritis. Kemudian jika nilai simpangan frekuensi bernilai negatif dan simpangan lendutan 
bernilai positif maka dapat dikatakan bahwa baik uji dinamik maupun uji statik memberikan kecenderungan yang sama yaitu struktur lebih lentur daripada hasil perhitungan secara teoritis.

Korelasi yang lain antara pengujian dinamik dan statik terhadap pemodelan adalah lendutan uji beban statik perkiraan berdasarkan perbandingan frekuensi hasil uji terhadap teoritis:

$\mathrm{u}_{\mathrm{aktual}}=\frac{\mathrm{u}_{\text {teori }}}{\left(\mathrm{f}_{\text {aktual }} / \mathrm{f}_{\text {teori }}\right)^{2}}$

Pada Tabel 4 ditunjukkan lendutan perkiraan jika menggunakan rumus diatas dibandingkan dengan lendutan aktual yang terukur.

Tabel 4. Korelasi pengujian vibrasi (dinamik) dan statik terhadap analisa pemodelan

\begin{tabular}{|c|c|c|c|c|c|c|c|c|c|}
\hline \multirow{2}{*}{ Type Struktur } & \multirow{2}{*}{ Jenis Struktur } & \multicolumn{2}{|c|}{ Frekuensi (Hz) } & \multicolumn{2}{|c|}{ Lendutan $(\mathrm{mm})$} & \multirow{2}{*}{\begin{tabular}{|c|} 
faktual/ \\
f teori \\
\end{tabular}} & \multirow[b]{2}{*}{$(\Delta f)^{2}$} & \multirow{2}{*}{\begin{tabular}{|l}
$\mathrm{U}(\mathrm{mm})$ \\
Perkiraan
\end{tabular}} & \multirow{2}{*}{\begin{tabular}{|c|}
$\% \mathrm{U}$ \\
perkiraan vs aktual
\end{tabular}} \\
\hline & & Aktual & Teoritis & Aktual & Teoritis & & & & \\
\hline \multirow{19}{*}{ Simple Span } & Steel box girder & 1.215 & 1.076 & 117.10 & 143.90 & 1.129 & 1.274 & 112.951 & $-3.54 \%$ \\
\hline & $\mathrm{X} 1$ & & & & & & & & \\
\hline & $61.9 \mathrm{~m}$ & & & & & & & & \\
\hline & Steel box girder & 2.800 & 2.900 & 20.47 & 19.12 & 0.966 & 0.932 & 20.510 & $0.20 \%$ \\
\hline & $\mathrm{X} 2$ & & & & & & & & \\
\hline & $35 \mathrm{~m}$ & & & & & & & & \\
\hline & & & & & & & & & \\
\hline & Steel box girder & 1.330 & 1.346 & 62.84 & 68.45 & 0.988 & 0.976 & 70.107 & $11.56 \%$ \\
\hline & $\mathrm{X} 3$ & & & & & & & & \\
\hline & $60 \mathrm{~m}$ & & & & & & & & \\
\hline & & & & & & & & & \\
\hline & Steel box girder & 1.420 & 1.360 & 68.68 & 67.82 & 1.044 & 1.090 & 62.210 & $-9.42 \%$ \\
\hline & $\mathrm{X} 4$ & & & & & & & & \\
\hline & $60 \mathrm{~m}$ & & & & & & & & \\
\hline & & & & & & & & & \\
\hline & Steel box girder & 1.400 & 1.360 & 69.22 & 71.11 & 1.029 & 1.060 & 67.105 & $-3.06 \%$ \\
\hline & X5 Uji Ulang & & & & & & & & \\
\hline & $60 \mathrm{~m}$ & & & & & & & & \\
\hline & Steel box girder & & & & & & & & $773 \%$ \\
\hline$\frac{\text { Simple Span }}{+}$ & $\frac{\text { Steel box girder }}{\mathrm{X} 6}$ & 1.440 & 1.340 & 64.03 & 79.66 & 1.075 & 1.155 & $68.980 \mid$ & $7.73 \%$ \\
\hline \multirow[t]{16}{*}{ Link Slab } & $60 \mathrm{~m}$ & & & & & & & & \\
\hline & & & & & & & & & \\
\hline & Steel box girder & 1.340 & 1.430 & 67.80 & 55.87 & 0.937 & 0.878 & \begin{tabular}{|l|l|}
63.627 & -12 \\
\end{tabular} & $-6.15 \%$ \\
\hline & $\mathrm{X} 7$ & & & & & & & & \\
\hline & $60 \mathrm{~m}$ & & & & & & & & \\
\hline & Tidak Dilanjutkan Ke Tahap III & & & & & & & & \\
\hline & \begin{tabular}{|l|} 
Aktual $>$ Teori \\
\end{tabular} & & & & & & & & \\
\hline & Steel bor oivdle & 1481 & 375 & 6020 & 6309 & 1077 & 1160 & 55.158 & $-8.38 \%$ \\
\hline & $\mathrm{X} 7$ & 1.401 & $1.5 / 3$ & 00.20 & 03.99 & 1.011 & 1.100 & 年 & $-0.50 \%$ \\
\hline & $60 \mathrm{~m}$ & & & & & & & & \\
\hline & Uji Ulang & & & & & & & & \\
\hline & Setelah Perkuatan & & & & & & & & \\
\hline & & & & & & & & & \\
\hline & Steel box girder & 1.220 & 1.150 & 69.11 & 75.77 & 1.061 & 1.125 & 67.328 & $-2.58 \%$ \\
\hline & $\mathrm{X} 8$ & & & & & & & & \\
\hline & $75 \mathrm{~m}$ & & & & & & & & \\
\hline \multirow{11}{*}{ Zontinuous Span } & Steel box girder & 1600 & 1385 & 31.26 & 43,38 & 1155 & 1335 & 32505 & $3.98 \%$ \\
\hline & $\mathrm{X} 9$ & & & & & & & & \\
\hline & $60 \mathrm{~m}$ & & & & & & & & \\
\hline & & & & & & & & & \\
\hline & Steel I girder & 0.9117 & 0.902 & 83.241 & 81.49 & 1.011 & 1.022 & 79.765 & $-4.18 \%$ \\
\hline & $\mathrm{X} 10$ & & & & & & & & \\
\hline & $120 \mathrm{~m}$ & & & & & & & & \\
\hline & & & & & & & & & \\
\hline & Steel I girder & 0.900 & 0.950 & 105.00 & 92.94 & 0.947 & 0.898 & 103.550 & $-1.38 \%$ \\
\hline & $\mathrm{X} 11$ & & & & & & & & \\
\hline & $120 \mathrm{~m}$ & & & & & & & & \\
\hline
\end{tabular}


Dari data Tabel tersebut dapat dikatakan bahwa pengujian dinamik mempunyai korelasi dengan uji beban atau uji statik dimana kita dapat memprediksikan lendutan yang akan terjadi dengan membagi lendutan teoritis dengan perbedaan frekuensi antara aktual dan teoritis dalam pangkat dua. Hasil dari perbandingan antara lendutan aktual dengan lendutan perkiraan masih dapat diterima yaitu dibawah $12 \%$.

Dilihat dari korelasi diatas, maka untuk pemeriksaan berkala pada struktur yang telah diuji tersebut dapat dipertimbangkan untuk dilakukan dengan pengujian vibrasi saja. Hal ini dikarenakan pada struktur yang telah beroperasi cukup memungkinkan untuk dilakukan penutupan jalan dalam waktu yang lebih singkat (1 atau 2 jam saja), berbeda halnya dengan pengujian statik yang memerlukan waktu cukup lama (kurang lebih satu hari).

\section{Perubahan suhu}

Pengaruh perubahan suhu terhadap struktur jembatan baja dapat kita ketahui melalui settlement sensor terlihat pada Gambar 10 dan 11. Settlement sensor dapat kita pasang terlebih dahulu sebelum dimulai uji beban minimal 24 jam sehingga dapat diamati pengaruh suhu tersebut akibat beban $0 \%$.

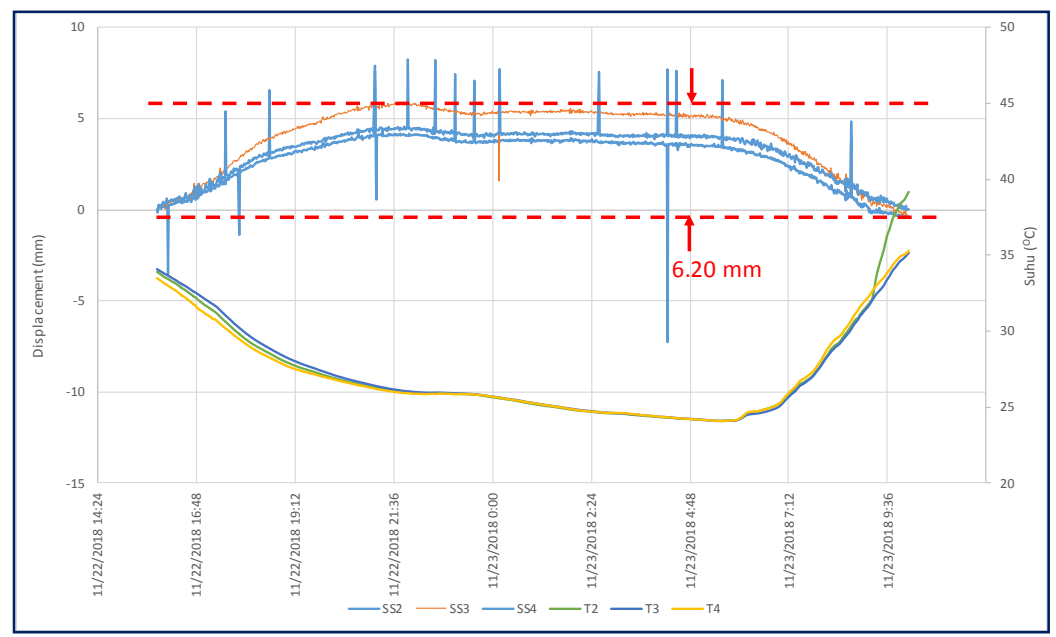

Gambar 10. Displacement akibat perubahan suhu sebelum uji beban pada struktur simple span steel box girder

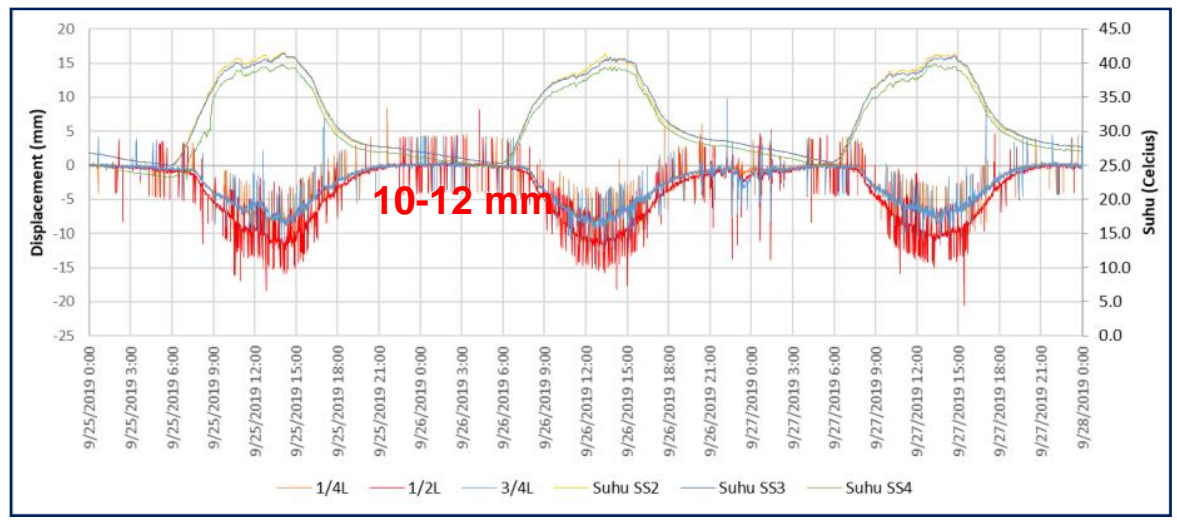

Gambar 11. Displacement akibat perubahan suhu sebelum uji beban pada struktur simple span steel box girder 
Pada Gambar 10 dan Gambar 11 terlihat bahwa perbedaan lendutan akibat perubahan suhu tanpa beban yang terjadi adalah sekitar $6.2 \mathrm{~mm}$ dan $12 \mathrm{~mm}$. Perbedaan lendutan terjadi pada pagi hari yaitu sekitar jam 6 hingga sore hari menjelang malam sekitar jam 20. Pada jam 20 malam sampai jam 6 pagi tidak terlihat adanya perubahan lendutan yang signifikan.

Angka pada grafik sebelah kiri menunjukkan besarnya lendutan yang terjadi sedangkan angka disebelah kanan adalah besarnya suhu yang terjadi. SS2, SS3 dan SS4 adalah titik settlement sensor yang dipasang sedangkan $\mathrm{T} 2$, T3 dan T4 adalah suhu yang terjadi pada titik tersebut. Titik titik tersebut dipasang settlement sensor di $1 / 4$ bentang, $1 / 2$ bentang dan $3 / 4$ bentang.

\section{KESIMPULAN DAN SARAN}

\section{Kesimpulan}

Pengujian vibrasi dan pengujian statik yang telah dilakukan pada beberapa sistem struktur (simple span, simple span + link slab dan continuous span) menghasilkan data-data yang dapat dianalisa dan dibandingkan dengan hasil pemodelan atau teoritis. Kesimpulan yang dapat diambil adalah sebagai berikut :

- Hasil korelasi antara prediksi lendutan uji (berdasarkan uji vibrasi dan teoritis) terhadap lendutan uji beban statik cukup mendekati dengan perbedaan kurang dari $12 \%$.

- Hasil uji beban vibrasi seluruh pengujian memberikan nilai kondisi yang baik atau utuh berdasarkan penilaian kondisi bangunan atas jembatan dengan nilai $D_{\text {rel }}$ maksimal $5.3 \%$ (minus berarti kondisi aktual lebih kaku dibandingkan perencanaan sehingga bisa dikatakan lebih aman).

- Lendutan uji bisa diprediksi dengan data dari pengujian vibrasi (frekuensi vertikal alami hasil uji) dan pemodelan atau teoritis (frekuensi vertikal alami teoritis dan lendutan teoritis).

- Beban suhu cukup signifikan sehingga dalam uji beban harus dilakukan pemantauan selama minimal 24 jam tanpa beban sehingga bisa dilakukan koreksi lendutan akibat perubahan suhu.

- Dilihat dari korelasi diatas, maka untuk pemeriksaan berkala pada struktur yang telah diuji tersebut dapat dipertimbangkan untuk dilakukan dengan pengujian vibrasi saja. Hal ini dikarenakan pada struktur yang telah beroperasi cukup memungkinkan untuk dilakukan penutupan jalan dalam waktu yang lebih singkat (1 atau 2 jam saja), berbeda halnya dengan pengujian statik yang memerlukan waktu cukup lama (kurang lebih satu hari).

\section{Saran}

Saran dari penelitian ini adalah :

- Pengujian malam hari dapat dilakukan untuk meminimalisir pengaruh perubahan suhu.

- Pengujian kemiringan struktur terutama untuk struktur yang berbentuk lengkung dapat dilakukan dengan beban yang tidak simetris, hal ini dapat dilakukan pada pengujian selanjutnya yang dapat lebih dikembangkan lagi.

- Pengujian dengan Eccentric Mass Shaker bisa dilakukan guna mendapatkan pola ragam getar dan frekuensi lateral.

- Pemeliharaan berkala pada struktur yang telah diuji dapat dipertimbangkan hanya dengan pengujian vibrasi saja tanpa melakukan pengujian statik berdasarkan data hasil korelasi tersebut (data diambil saat pembangunan baru selesai), apabila nilai frekuensi yang terjadi pada pengujian vibrasi dalam pemeriksaan berkala (5, 10 atau 20 tahun) menjadi lebih rendah maka perlu dilakukan pemeriksaan struktur secara lebih detail karena kekakuan struktur menurun. Kekakuan struktur menurun dalam periode tertentu dapat terjadi kemungkinan disebabkan oleh beberapa hal diantaranya mutu baja yang menurun, adanya korosi, sambungan baut yang menjadi kendor dan lain sebagainya. 


\section{REFERENSI}

BS 6841-1987. (1987) Guide to Measurement and Evaluation of Human Exposure to WholeBody Mechanical Vibration and Repeated Shock. British Standard.

Craig Jr, Roy R. (1981). Structural Dynamics : An Introduction to Computer Methods. Department of Aerospace Engineering and Engineering Mechanics The University of Texas at Austin.

ISO 2631-1. (1997). Mechanical Vibration and Shock Evaluation of Human Exposure to Whole Body Vibration. International Organization For Standardization.

PU.(2002). Penilaian Kondisi Jembatan untuk Bangunan Atas dengan Cara Uji Getar. Departemen Permukiman dan Prasarana Wilayah.

Rionaldo, P. (2014). Aplikasi Pengujian Vibrasi Pada Perkuatan Struktur Pelat Lantai. Universitas Indonesia.

SNI 1725-2016. Pembebanan Untuk Jembatan. Jakarta. Badan Standarisasi Nasional.

Wahyuni, E. (2012). Studi Kelakuan Dinamis Struktur Jembatan Penyeberangan Orang (JPO) Akibat Beban Individual Manusia Bergerak. Jurnal Teknik Sipil. 19(3). pp181-194 . DOI: $\underline{10.5614 / j t s .2012 .19 .3 .1 .}$. 